Article

\title{
Consumers' Perception and Willingness to Pay for Eco-Labeled Seafood in Italian Hypermarkets
}

\author{
Sergio Vitale ${ }^{1}$, Federica Biondo ${ }^{2}$, Cristina Giosuè ${ }^{3}$, Gioacchino Bono ${ }^{1}(\mathbb{D}$, \\ Charles Odilichukwu R. Okpala ${ }^{4}\left(\right.$ ), Ignazio Piazza ${ }^{5}$, Mario Sprovieri ${ }^{5}$ and Vito Pipitone ${ }^{6,7, *(1)}$ \\ 1 Institute for Biological Resources and Marine Biotechnologies (IRBIM), National Research Council of \\ Italy (CNR), 91026 Mazara del Vallo, Italy; sergio.vitale@cnr.it (S.V.); gioacchino.bono@cnr.it (G.B.) \\ 2 Department of Economics, Business and Statistics, University of Palermo, 90100 Palermo, Italy; \\ federica.biondo02@unipa.it \\ 3 Institute of Anthropic Impacts and Sustainability in Marine Environment (IAS), National Research Council \\ of Italy (CNR), 90100 Palermo, Italy; cristinagiosue@gmail.com \\ 4 Faculty of Biotechnology and Food Science, Wrocław University of Environmental and Life Sciences, \\ 51-630 Wrocław, Poland; charlesokpala@gmail.com \\ 5 Institute of Anthropic Impacts and Sustainability in Marine Environment (IAS), National Research Council \\ of Italy (CNR), 91021 Capo Granitola, Italy; ipiazza@libero.it (I.P.); mario.sprovieri@ias.cnr.it (M.S.) \\ 6 Institute for Studies on the Mediterranean (ISMed), National Research Council of Italy (CNR), \\ 90145 Palermo, Italy \\ 7 Department of Law, LUMSA University, 90145 Palermo, Italy \\ * Correspondence: vito.pipitone@cnr.it; Tel.: +390916810761
}

Received: 12 December 2019; Accepted: 26 January 2020; Published: 14 February 2020

\begin{abstract}
The aim of this paper is to discuss eco-labels for fish products, which are a useful tool to improve both seafood markets and strategies for sustainability management. In this study, 560 consumer-surveys were conducted in selected towns in northern and southern Italy. Both probit and linear regression modeling were used to measure consumers' perception and willingness to pay for anchovy eco-labels. Italian hypermarket consumers demonstrated attention to environmental features as well as to eco-products, at times, independent of income. The results of this study show that willingness to pay relates to gender, family situation, mass communication, environmental features, angler community, and store, along with information from eco-labels. Specifically, females appeared highly responsive to seafood eco-labels, and their preferences were informed by environmental aspects along with a strong intrinsic motivation to protect marine habitats. According to our analysis, seafood eco-labels could increase the consumers' willingness to pay between $16 \%-24 \%$ more for the product. Given that consumers' willingness to pay can reveal a new form of an "ecosystem approach to fishery management", there is a high chance that premium prices could become a tool for sustainable resource management.
\end{abstract}

Keywords: awareness; price premium; European anchovy; Mediterranean Sea

\section{Introduction}

An environmentally friendly approach to seafood consumption is becoming an important factor for the sustainable management of fishery resources [1,2]. Seafood eco-labels are relatively new, first introduced in the early 1990s as the 'Dolphin-Safe' label in the United States. These labels have continued to evolve and now include several different international 'sustainable' certifications. This approach has been based on three key principles consistent with the United Nations Food and Agriculture Organization Code of Conduct, which includes: (a) Fish stocks must be sustainable; (b) environmental impacts must be minimized; and (c) management practices must be effective [3]. In general, eco-labels 
are granted by non-governmental organizations (NGOs) like the Marine Stewardship Council (MSC) and Friend of the Sea, all aiming to provide sufficient reassurance to consumers regarding the sustainability of the fishery from which the products originated. Notably, producers have a role to play, especially in increasing the information provided to consumers with regards to the environmental impacts of the fishing methods employed. While various types of eco-labels can influence fishery governance and management over time, both consumers and retailers have to sustain the demand for eco-labels [4].

Strongly favoring the development of eco-friendly seafood, the European Commission (EC) supports both sustainable consumption and production to maximize market potential [5]. However, consumer willingness may not directly translate into consumer behavior, given the multiple barriers to sustainable consumption, including availability, affordability, convenience, product performance, conflicting priorities, skepticism, and force of habit [6,7]. Consumer behavior may be primarily influenced by quantifiable perceptions of environmental information on the label, not by intrinsic environmental concerns $[1,5,8]$. Jonell et al. [9] recently highlighted that an emotional component in consumer's decision-making, together with their knowledge of seafood eco-labels, could influence their consumption of sustainable fish products. Understanding the importance of eco-labels has often been difficult for consumers $[6,10]$. In fact, health and food safety concerns are generally their sole reasons for purchasing eco-labeled products $[1,5,11]$. Moreover, consumers who were likely to choose eco-labeled fishery products have been shown to have a greater consumption of seafood products, especially those that are fresh/wild-caught [12-16]. While consumer preferences can vary among species, an eco-label alone may be insufficient to attract consumers to those of less well-known species [13,17].

To date, there appears to be no study that has evaluated consumers' response to eco-labeled pelagic seafood products in a typical Italian hyper/supermarket. The nearest publication we found in Europe was one that explored whether eco-labels of fish products determined a price premium at a UK supermarket, in which an MSC ecolabel was among those compared [3]. Additionally, the availability of information about seafood products could support consumers in their decision-making process and consequently encourage them to pay a price premium. Typically, such information, including the name of the species and their biological features, the origin, the brand, and the fishing method, as well as the management measures and governance systems, can be considered as useful in implementing sustainable exploitation [18]. Therefore, the specific objective of the current study is to evaluate consumers' responsiveness to a proposed eco-labeled pelagic seafood product in Italian hypermarkets. A number of strategies for improving the seafood market, as well as the sustainable management of fishery resources, will be considered.

\section{Materials and Methods}

\subsection{Survey}

The survey conducted assessed consumer awareness and willingness to pay (WTP) for the European anchovy (Engraulis encrasicolus; Linnaeus, 1758), proposing two different eco-labels. The first one involved fish caught using gear with a low impact on habitats (LIH). The second one involved fish caught in unpolluted areas, which are therefore seen as certified 'blue' fishing grounds (BFG). The European anchovy is among the most valuable pelagic fish species found across the Mediterranean Sea. Although fishing activities have remained stable overall, fluctuation of this pelagic fish in landing numbers and biomass still shows some alarming signs [19].

The survey considered a non-probabilistic quota sampling of AUCHAN S.p.A. consumers, interviewed face to face by questionnaire. The locations of the survey were fish counters in AUCHAN S.p.A. stores; one in Palermo (Sicily, south of Italy) and the other in Milano (north of Italy). The locations were chosen, not only to compare two different socioeconomic regions, but also to offer a heterogeneous yet representative sampling, resembling a published reference [20]. In Milano, the population is characterized by relatively high demographic dynamics with the lowest unemployment 
rate at a national level and a lack of a strong culture of seafood consumption. Conversely, Palermo has relatively low demographic dynamics, a high unemployment rate, and a rich culinary tradition of seafood consumption. In this context, a quota sampling of three age groups (18-25 years-old 10\%; 26-65 years-old $\sim 70 \%$; $>65$ years-old $\sim 20 \%$ ), representing the main socio-demographic determinants among Italian consumers [21,22] was considered. A sample size of 550-600 interviews was predefined according to cost efficiency and time effectiveness.

The research employed the questionnaire design proposed by Brécard et al. [23], adapted for the purposes of this survey. In particular, new questions were formulated to assess consumers' WTP for eco-labeled seafood [24-26]. The questionnaire consisted of 35 questions, including the usual sociodemographic variables of gender, age, family and professional situation, place of residence, and monthly-declared income. Respondents expressed their overall fishing knowledge, environmental motivations, intrinsic motivations, qualitative seafood preference, and their WTP for eco-labeled anchovies. It is notable to highlight that only consumers approaching the fish counter to buy seafood were interviewed. Considering the specificity of the issues proposed, the qualitative and quantitative information required, as well as the potential distraction of the persons interviewed, the questionnaire does not include any filter variables. Indeed, there is some evidence that filter questions could discourage the informed interviewee from expressing their true opinion [27]. Table 1 shows a succinct illustration of the questionnaire structure by themes, number of items, questions, and response types.

Table 1. Succinct illustration of questionnaire design by theme, items, questions, and response types.

\begin{tabular}{cccc}
\hline Themes & No. of Questions & Question Type & Response Type \\
\hline Overall fishing knowledge & 9 & 7 Questions: Dichotomous & All closed \\
Environmental motivations & 3 & 2 Questions: Multiple-choice & All dichotomous \\
Intrinsic motivations & 7 & 4 Questions: Multiple-choice & All closed \\
2 Questions: Dichotomous & 1 Question: Multiple-choice & 1 closed and 3 open \\
$\begin{array}{c}\text { Wualitlingness to pay (WTP) for } \\
\text { Eco-labeled anchovy }\end{array}$ & 4 & 3 Questions: Dichotomous & 3 closed and 2 open \\
\hline
\end{tabular}

Key: Answer type: Open/Closed; Question type: Dichotomous/Multiple-choice.

Prior to this study, the questionnaire was presented to AUCHAN S.p.A. store authorities for approval to ensure that it respected their prescribed customer relations policy. Although the questionnaires would be anonymous, the participants were informed that the data processing would be conducted in accordance with the EC Directive 95/46/CE (24 October 1995) for the protection, confidentiality, and anonymity of personal data.

The interview was conducted face-to-face with AUCHAN S.p.A. shoppers using a non-probabilistic quota sampling. Trained researchers from the National Research Council of Italy conducted the interviews. The consumers were interviewed individually for approximately 5 minutes. Overall, 560 questionnaires were collected within 4 weeks on the same weekdays.

\subsection{Data Analysis}

Descriptive analysis of the participants' socioeconomic characteristics (gender, age, family situation, income earners, and income) by location (Palermo and Milano) was undertaken and tested by a nonparametric Kolmogorov-Smirnov test (K-S test). Principal component analysis (PCA) [28] was carried out to identify the 'latent' variables influencing consumers' response to eco-labels. To improve the description of the underlying relation between the initial set of variables and the 'latent' variables, the rotation method of Varimax with Kaiser's normalization was applied. 
A binary probit model was used to evaluate the responsiveness of consumers to low-impact habitats (LIH) or certified 'blue' fishing grounds (BFG) anchovy eco-labels. The probability model is defined as follows:

$$
\operatorname{Pr}\left(Y=1 \mid X=x_{i}\right)=\left(x^{T} \beta\right)=\frac{1}{\sqrt{2 \pi}} \Phi \int_{-\infty}^{x^{T} \beta} e^{-z^{2}} d z
$$

where $Y$ is the binary response variable that take values 0 (when the consumers declare no interest in eco-labelled seafood) and 1 (when the consumers declare interest in eco-labelled seafood); $\Phi$ is the standard normal cumulative density function, $\beta$ is a vector of the independent variable coefficient estimates, and $X$ is a vector of the independent variables.

One model was deliberately given more variables than the others, with the goal of determining whether this would strengthen its power and increase the chance of establishing the statistical significance of the employed variables of interest. Model 1 considered gender, age, income earners, income, family situation, and principal components (means of technical communication (Component 1), attention to fish quality (Component 2), attention to environmental features (Component 3 ), and means of mass communication (Component 4]), whereas Model 2 considered, not only all of Model 1, but also contaminant limits, store, and the purchase of other eco-label products.

According to the theory, the consumer makes their choice by taking into account their preferences and budget constraints. For this reason, the income variable was introduced as a proxy of budget constraint, and in order to represent the consumer preferences, gender, age, income earners, and family situation variables were used. The first two variables (gender and age) consider the individual dimensions, while the last two variables (income earners and family situation) add family dimensions to the consumer preference model.

To test the robustness of the model, the Akaike information criterion (AIC) was applied.

Furthermore, a linear model relating the response, $y$, to several predictors has been used in the following form:

$$
Y=\beta_{0}+\beta_{1} X_{1}+\beta_{2} X_{2}+\ldots+\beta_{k} X_{k}+\varepsilon
$$

where $Y$ is the continuous response variable, $\beta$ represents regression coefficients, $X$ is a vector of the independent variables, and the random variable $\varepsilon$ is the error term in the model.

The continuous response variables to this model are WTP-LIH and WTP-BFG. A linear regression model approach was then applied in three different contexts, in function of the explanatory variables considered. Model 1 considered the principal components (1-4) in addition to the consumers' responsiveness to LIH and BFG, respectively. Model 2 considered all of Model 1 in addition to gender, age, income earners, income, family situation, and contaminant limits. Model 3 considered all independent variables of Model 2, in addition to the store. This three-model approach allowed for the observation of any significant effects arising from the addition of variables. For any regression model to be considered statistically significant, the $p$-value must be $<0.10$.

In accordance with our questionnaire design, the independence of the two models (binary probit regression model and linear regression model) was tested by the Heckman specification [29]. For the LIH ecolabel, the correlation coefficient between the two models was close to zero $(\rho=-0.0957)$. Likewise, for the BFG ecolabel, the correlation coefficient, $\rho$, between the two models was 0.4720 . Likelihood-ratio (LR) tests for independent equations $(\rho=0)$ showed that the null hypothesis cannot be rejected $\left(\right.$ LIH ecolabel $X^{2}=0.07, p$-value $=0.7858$; BFG ecolabel $X^{2}=2.17, p$-value $=0.1411$ ). Accordingly, selection bias is not a significant issue, both for LIH and BFG eco-labels; therefore, the two models (binary probit regression model and linear regression model) were estimated as separate equations.

\section{Results}

Table 2 shows sample descriptive characteristics of the socio-economic situation (gender, age, income earners, and income) of the two studied locations, which we considered representative of the Italian population [21,22]. A total of 322 and 238 interviews were carried out in Palermo and Milano, 
respectively. Male respondents participated less frequently in Palermo (46.0\%) compared to Milano $(50.4 \%)$, with a higher number of interviewees in the age classes $46-65$ (Palermo $=49.4 \%$; Milano $=$ $41.2 \%)$. The income earners were higher in Milano compared to Palermo.

Table 2. Sample descriptive characteristics of the socio-economic situation of the two studied locations in Italy.

\begin{tabular}{|c|c|c|c|c|c|}
\hline \multirow[b]{2}{*}{ Variables } & \multirow{2}{*}{$\begin{array}{c}\text { Italia } \\
\% \text { Dis. }\end{array}$} & \multicolumn{2}{|c|}{ Sample $(n=560)$} & \multirow{2}{*}{$\begin{array}{c}\text { Palermo }(\mathrm{n}=322) \\
\text { \% Dis. }\end{array}$} & \multirow{2}{*}{$\begin{array}{c}\text { Milano }(\mathrm{n}=238) \\
\text { \% Dis. }\end{array}$} \\
\hline & & Obs. & \% Dis. & & \\
\hline Gender & & 560 & & & \\
\hline Female & $51.3 \%^{\mathrm{a}}$ & & $51.8 \%$ & $54.0 \%$ & $49.6 \%$ \\
\hline Male & $48.7 \%{ }^{a}$ & & $48.2 \%$ & $46.0 \%$ & $50.4 \%$ \\
\hline Age (years) & & 545 & & & \\
\hline $18-25$ & $11.2 \%{ }^{a}$ & & $2.1 \%$ & $2.2 \%$ & $2.1 \%$ \\
\hline $26-45$ & $28.7 \%{ }^{a}$ & & $34.2 \%$ & $28.9 \%$ & $39.5 \%$ \\
\hline $46-65$ & $34.1 \%$ a & & $45.3 \%$ & $49.4 \%$ & $41.2 \%$ \\
\hline$>65$ & $26 \%{ }^{a}$ & & $18.4 \%$ & $19.6 \%$ & $17.2 \%$ \\
\hline Income earners & & 528 & & & \\
\hline Yes & $67 \% \mathrm{~b}$ & & $79.8 \%$ & $77.6 \%$ & $82.0 \%$ \\
\hline No & $33 \% \mathrm{~b}$ & & $20.2 \%$ & $22.4 \%$ & $18.0 \%$ \\
\hline $\begin{array}{l}\text { Income } \\
(€ / \text { month) }\end{array}$ & & 341 & & & \\
\hline$<1000$ & $30.6 \% \mathrm{~b}$ & & $11.6 \%$ & $14.5 \%$ & $8.8 \%$ \\
\hline 1000-1999 & $39.1 \% \mathrm{~b}$ & & $58.1 \%$ & $58.8 \%$ & $57.4 \%$ \\
\hline $2000-3000$ & $12.7 \% \mathrm{~b}$ & & $24.3 \%$ & $20.9 \%$ & $27.8 \%$ \\
\hline$>3000$ & $17.6 \% \mathrm{~b}$ & & $5.9 \%$ & $5.8 \%$ & $6.0 \%$ \\
\hline
\end{tabular}

Notes: Sources for National data are as follows: ${ }^{a}$ Italian National Institute of Statistics (ISTAT); ${ }^{\mathrm{b}}$ Ministry of Economy and Finances (MEF).

Figure 1 shows the overall consumer response to acceptable price premiums for eco-labeled anchovies of LIH and BFG. About $95 \%$ of the respondents were willing to pay a price premium. In particular, approximately $70 \%$ of the overall respondents were willing to pay premiums between $1 \%$ and $20 \%$. The interviewees' responsiveness to LIH and BFG seems to be somewhat different. In fact, consumers showed an overall higher inclination towards LIH (75\%) than BFG (70\%), even though the price premium range of $11 \%-20 \%$ was higher for BFG (35\%).

From Table 3, the rotated component matrix shows significant $(p<0.05)$ factorial weights for consumers' responses. Specific to Component 1, PCA revealed a difference for specialized fishing and scientific magazines, professional publications, campaigns and documents from environmental NGOs, and initiatives emanating from ministries and/or local authorities. Conversely, television, newspapers, and the internet differed for Component 2, while pollution, climate change, and high catches differed for Component 3 . In addition, occupation and belonging to a fisherman's family differed for Component 4. Considering these factorial weights, it is possible to contextualize these 'latent variables' to help form the construct of the main components, which can then be employed in both probit and linear models. Specifically, the main components identified were as follows: No. 1 $=$ Means of technical communication, No. $2=$ Means of mass communication, No. $3=$ Attention to environmental features, and No. $4=$ Angler community. 


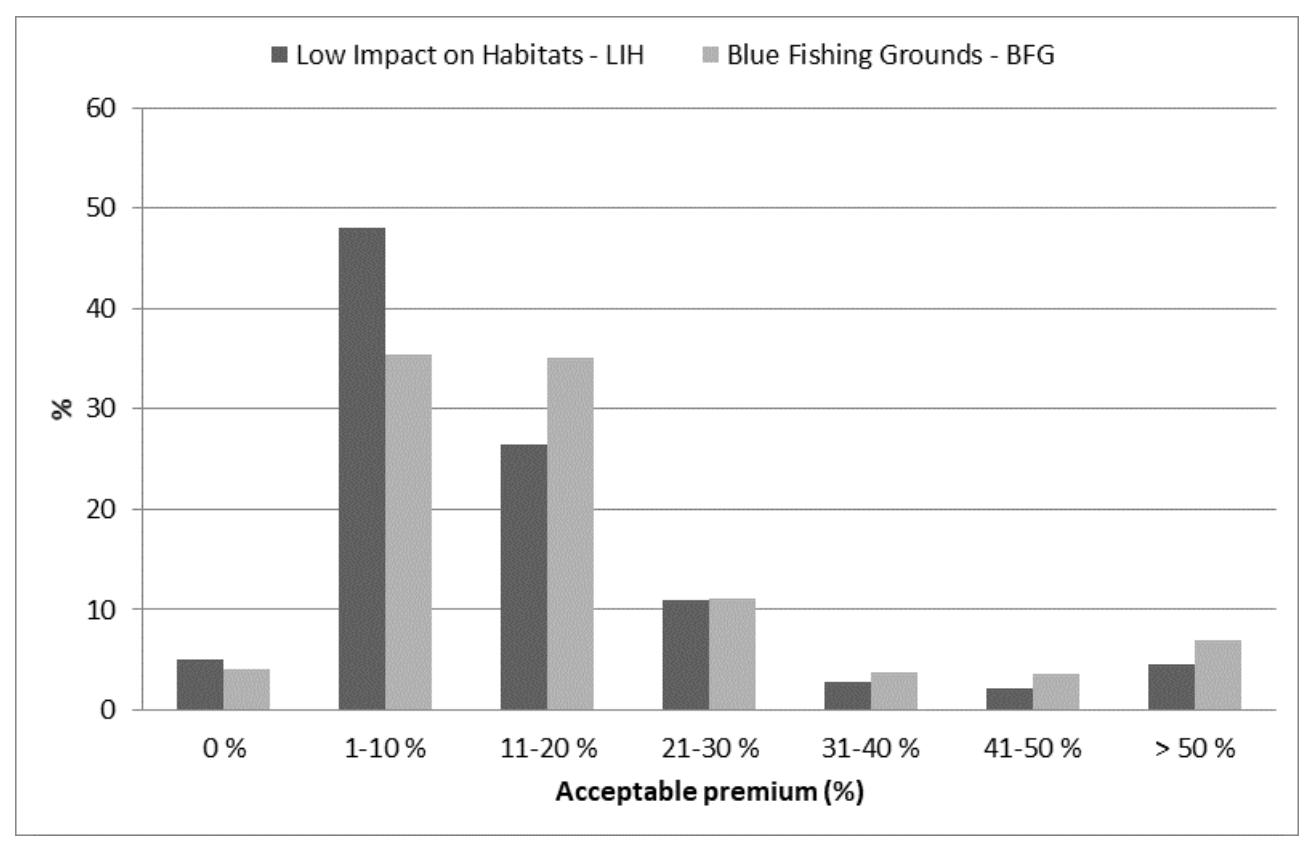

Figure 1. Overall consumer responses to acceptable price premiums for eco-labeled anchovy of low-impact on habitats (LIH) and 'blue' fishing grounds (BFG).

Table 3. Rotated component matrix of weighable factors complementing consumers' responses.

\begin{tabular}{|c|c|c|c|c|}
\hline \multirow{2}{*}{ Weighable Factors } & \multicolumn{4}{|c|}{ Component } \\
\hline & 1 & 2 & 3 & 4 \\
\hline Specialized fishing magazines & 0.428 & & & \\
\hline Scientific magazines & 0.695 & & & \\
\hline Publications from professionals & 0.773 & & & \\
\hline $\begin{array}{l}\text { Campaigns and documents for } \\
\text { environmental non-governmental } \\
\text { organizations (NGOs) }\end{array}$ & 0.787 & & & \\
\hline $\begin{array}{l}\text { Initiatives emanating from Ministries } \\
\text { and/or Local Bodies }\end{array}$ & 0.768 & & & \\
\hline Television & & 0.778 & & \\
\hline Daily/Weekly Newspapers & & 0.785 & & \\
\hline Internet & & 0.444 & & \\
\hline Pollution & & & 0.731 & \\
\hline Climate change & & & 0.846 & \\
\hline High catches & & & 0.531 & \\
\hline Angler & & & & 0.805 \\
\hline Member of angler family & & & & 0.720 \\
\hline
\end{tabular}

Extraction method: Principal component analysis (PCA). Rotation method: Varimax with Kaiser's normalization.

Table 4 shows all variables considered in the analyses as well as their descriptive statistics. Of 12 variables, 4 were continuous (WTP-LIH, WTP-BFG, Age, and Income) and 8 were dummy (LIH, BFG, Gender, Income earners, Family situation, Contaminant limits, Store, and Other eco-products). 
Table 4. Variables and their descriptive statistics.

\begin{tabular}{|c|c|c|c|}
\hline \multicolumn{4}{|c|}{ QUANTITATIVE VARIABLES } \\
\hline Variable & Description & Mean & SD \\
\hline WTP-LIH & $\begin{array}{l}\text { Continuous variable to indicate the WTP } \\
\text { for product with LIH Label, } € / \mathrm{Kg}\end{array}$ & 0.931 & 1.155 \\
\hline WTP-BFG & $\begin{array}{l}\text { Continuous variable to indicate the WTP } \\
\text { for product with BFG Label, } € / \mathrm{Kg}\end{array}$ & 1.19 & 1.434 \\
\hline Age & Discrete variable, minimum value 18 years & 51.4 & 15.1 \\
\hline Income & Continuous variable, $€ /$ month & 1732 & 657.249 \\
\hline \multicolumn{4}{|c|}{ QUALITATIVE VARIABLES } \\
\hline Variable & Description & \multicolumn{2}{|c|}{ Proportion } \\
\hline $\mathrm{LIH}$ & $\begin{array}{l}\text { Dummy variable for LIH Label: } 1 \text { if present, } \\
\text { 0 if not }\end{array}$ & \multicolumn{2}{|c|}{0.969} \\
\hline BFG & $\begin{array}{l}\text { Dummy variable for BFG Label: } 1 \text { if } \\
\text { present, } 0 \text { if not }\end{array}$ & \multicolumn{2}{|c|}{0.945} \\
\hline Gender & $\begin{array}{l}\text { Dummy variable for male and female sex: } 1 \\
\text { if female, } 0 \text { if male }\end{array}$ & \multicolumn{2}{|c|}{0.521} \\
\hline Income earners & Dummy variable: 1 if employed, 0 if not & \multicolumn{2}{|c|}{0.794} \\
\hline Family situation & $\begin{array}{c}\text { Dummy variable: } 1 \text { if other family situation, } \\
0 \text { if living alone }\end{array}$ & \multicolumn{2}{|c|}{0.889} \\
\hline Contaminant limits & $\begin{array}{c}\text { Dummy variable to indicate if contaminant } \\
\text { limits is known: } 1 \text { if so, } 0 \text { if not }\end{array}$ & \multicolumn{2}{|c|}{0.659} \\
\hline Store & $\begin{array}{c}\text { Dummy variable for store city: } 1 \text { if Milano, } \\
0 \text { if Palermo. }\end{array}$ & \multicolumn{2}{|c|}{0.425} \\
\hline Other eco-products & $\begin{array}{l}\text { Dummy variable to indicate if other } \\
\text { eco-products are bought: } 1 \text { if so, } 0 \text { if not }\end{array}$ & \multicolumn{2}{|c|}{0.43} \\
\hline
\end{tabular}

Table 5 shows the results of the measurement of consumers' awareness to eco-labels in the models. Models 1-LIH and 2-LIH measured the effect of independent variables on LIH (as dependent variables). Similarly, Models 1-BFG and 2-BFG measured the effect of independent variables on BFG (as dependent variables). The full probability models were defined as follows:

$$
\begin{aligned}
\operatorname{Pr}(\text { LIH }=1 \mid X= & \left.x_{i}\right) \\
& =\Phi\left(\beta_{0}+\beta_{1} \text { Gender }+\beta_{2} \text { Age }+\beta_{3} \text { Income earners }+\beta_{4}\right. \text { Income } \\
& +\beta_{5} \text { Family situation }+\beta_{6} C 1+\beta_{7} C 2+\beta_{8} C 3+\beta_{9} C 4 \\
& \left.+\beta_{10} \text { Contaminant limits }+\beta_{11} \text { Store }+\beta_{12} \text { Other eco products }\right) \\
\operatorname{Pr}(B F G=1 \mid X= & \left.x_{i}\right) \\
& =\Phi\left(\beta_{0}+\beta_{1} \text { Gender }+\beta_{2} \text { Age }+\beta_{3} \text { Income earners }+\beta_{4}\right. \text { Income } \\
& +\beta_{5} \text { Family situation }+\beta_{6} C 1+\beta_{7} C 2+\beta_{8} C 3+\beta_{9} C 4 \\
& \left.+\beta_{10} \text { Contaminant limits }+\beta_{11} \text { Store }+\beta_{12} \text { Other eco products }\right)
\end{aligned}
$$

It was found that non-income earners were more sensitive to LIH ( $p<0.01)$. Conversely, income and other eco-labeled product purchases influenced BFG $(p<0.01)$. The respondents' attention to environmental features (Component 3) was statistically significant for Model 2-LIH and BFG. The AIC reductions from 142.89 (Model 1-LIH) to 140.96 (Model 2-LIH) and 177.48 (Model 1-BFG) to 155.71 (Model 2-BFG) support the robustness of the models. 
Table 5. Consumers' awareness of low-impact habitats (LIH) or 'blue' fishing grounds (BFG) anchovy eco-labels.

\begin{tabular}{|c|c|c|c|c|}
\hline \multirow{2}{*}{ Variables } & \multicolumn{2}{|c|}{ LIH } & \multicolumn{2}{|c|}{ BFG } \\
\hline & Model 1 & Model 2 & Model 1 & Model 2 \\
\hline \multirow[t]{2}{*}{ Intercept } & $2.6306 * * *$ & $2.5460 * * *$ & 1.0826 & 0.1225 \\
\hline & $(0.7718)$ & $(0.8155)$ & $(0.6834)$ & $(0.7551)$ \\
\hline \multirow[t]{2}{*}{ Gender } & -0.1407 & -0.1636 & 0.1721 & 0.2730 \\
\hline & $(0.2505)$ & $(0.2648)$ & $(0.2366)$ & $(0.2686)$ \\
\hline \multirow[t]{2}{*}{ Age } & -0.0091 & -0.0115 & 0.0035 & 0.0061 \\
\hline & $(0.0080)$ & $(0.0085)$ & $(0.0073)$ & $(0.0082)$ \\
\hline \multirow[t]{2}{*}{ Income earners } & $-0.7774 * * *$ & $-0.7929 * * *$ & 0.0595 & 0.1173 \\
\hline & $(0.4450)$ & $(0.4807)$ & $(0.2654)$ & $(0.3016)$ \\
\hline \multirow[t]{2}{*}{ Income } & 0.0001 & 0.0001 & $0.0005^{* * *}$ & $0.0006^{* * *}$ \\
\hline & $(0.0001)$ & $(0.0001)$ & $(0.0001)$ & $(0.0002)$ \\
\hline \multirow{2}{*}{ Family situation } & 0.2951 & 0.3986 & -0.5351 & -0.5039 \\
\hline & $(0.3171)$ & $(0.3375)$ & $(0.4783)$ & $(0.5256)$ \\
\hline \multirow{2}{*}{ Means of technical communication (C1) } & 0.1148 & 0.1063 & -0.0331 & -0.0307 \\
\hline & $(0.1737)$ & $(0.1793)$ & $(0.0454)$ & $(0.0525)$ \\
\hline Means of mass communication (C2) & -0.0597 & -0.0576 & $\begin{array}{l}-0.0409 \\
(0.0670)\end{array}$ & $\begin{array}{l}-0.0729 \\
(0.0750)\end{array}$ \\
\hline \multirow{2}{*}{ Attention to environmental features (C3) } & $\begin{array}{c}(0.0 / 63) \\
0.1182\end{array}$ & $\begin{array}{c}(0.0810) \\
0.1362 * * *\end{array}$ & $0.1503 * * *$ & $0.1681 * * *$ \\
\hline & $(0.0762)$ & $(0.0811)$ & $(0.0677)$ & $(0.07959)$ \\
\hline \multirow[t]{2}{*}{ Angler community (C4) } & 0.0625 & 0.0395 & 0.0003 & -0.0661 \\
\hline & $(0.1001)$ & $(0.1025)$ & $(0.0782)$ & $(0.0868)$ \\
\hline Contaminant limits & & $\begin{array}{l}0.0328 \\
(0.2676)\end{array}$ & & 0.3880 \\
\hline \multirow[t]{2}{*}{ Store } & & -0.1549 & & -0.1186 \\
\hline & & $(0.2686)$ & & $(0.2811)$ \\
\hline \multirow[t]{2}{*}{ Other eco-products } & & 0.3054 & & $0.9843^{* * *}$ \\
\hline & & $(0.2701)$ & & $(0.3375)$ \\
\hline Null deviance & 135.29 & 129.71 & 175.30 & 164.76 \\
\hline Residual deviance & 122.89 & 114.96 & 157.48 & 129.71 \\
\hline AIC & 142.89 & 140.96 & 177.48 & 155.71 \\
\hline Pseudo $R^{2}$ (McFadden) & 0.1987 & 0.2377 & 0.2143 & 0.3006 \\
\hline No of cases & 509 & 453 & 446 & 422 \\
\hline
\end{tabular}

Key: C1-C4: Components 1-4; Levels of statistical significance: $<0.01\left(^{(* *}\right),<0.05\left(^{* *}\right),<0.10\left(^{*}\right)$; bolded digits indicate statistically significant values.

Table 6 shows the results of the WTP estimations. Models 1, 2, and 3 WTP-LIH measured the effect of independent variables on "WTP-LIH" (as dependent variable). Similarly, Models 1, 2, and 3 WTP-BFG evaluated the effect of independent variables on "WTP-BFG" (as dependent variable). The full linear models were defined as follows:

$$
\begin{aligned}
\text { WTP }- \text { LIH }= & \left(\beta_{0}+\beta_{1} \text { Gender }+\beta_{2} \text { Age }+\beta_{3} \text { Income earners }+\beta_{4}\right. \text { Income } \\
& +\beta_{5} \text { Family situation }+\beta_{6} C 1+\beta_{7} C 2+\beta_{8} C 3+\beta_{9} C 4 \\
& +\beta_{10} \text { Contaminant limits }+\beta_{11} \text { Store }+\beta_{12} \text { Other eco products } \\
& \left.+\beta_{13} \text { Consumer awareness }\right) \\
\text { WTP }-B F G= & \left(\beta_{0}+\beta_{1} \text { Gender }+\beta_{2} \text { Age }+\beta_{3} \text { Income earners }+\beta_{4}\right. \text { Income } \\
& +\beta_{5} \text { Family situation }+\beta_{6} \mathrm{C} 1+\beta_{7} \mathrm{C} 2+\beta_{8} C 3+\beta_{9} C 4 \\
& +\beta_{10} \text { Contaminant limits }+\beta_{11} \text { Store }+\beta_{12} \text { Other eco products } \\
& \left.+\beta_{13} \text { Consumer awareness }\right)
\end{aligned}
$$

Overall, the variables of gender, means of mass communication (Component 2), and store appeared consistent with high statistical significance for all models. Income earners was statistically significant only for WTP-LIH Model 2, while family situation was significant in WTP-LIH Model 2 and WTP-BFG Model 2. Attention to environmental features (Component 3) was statistically significant for all WTP-LIH models. Angler community (Component 4) was statistically significant for WTP-LIH Models 1-3 and WTP-BFG Model 2. Consumers' awareness was statistically significant for WTP-BFG Model 1 and Model 2. Moreover, the model of variables resulted in an increase in explained 
variance (R-sq-adjusted) in either WTP-LIH or WTP-BFG from 0.0995 up to 0.4635 and 0.0777 up to 0.3753 , respectively.

Table 6. Willingness to pay (WTP) for low-impact habitats (LIH) or certified 'blue' fishing grounds (BFG) anchovy eco-labels.

\begin{tabular}{|c|c|c|c|c|c|c|}
\hline \multirow{2}{*}{ Variables } & \multicolumn{3}{|c|}{ WTP-LIH } & \multicolumn{3}{|c|}{ WTP-BFG } \\
\hline & Model 1 & Model 2 & Model 3 & Model 1 & Model 2 & Model 3 \\
\hline Intercept & $\begin{array}{c}5.8173 * * * \\
(0.4559)\end{array}$ & $\begin{array}{c}6.4480 * * * \\
(6.5820)\end{array}$ & $\begin{array}{l}6.9990 * * * \\
(0.5106)\end{array}$ & $\begin{array}{c}5.0615 * * * \\
(0.6690)\end{array}$ & $\begin{array}{c}\mathbf{5 . 0 9 7 7} * * * \\
(0.9003)\end{array}$ & $\begin{array}{c}6.4760 * * * \\
(0.7582)\end{array}$ \\
\hline Gender & & $\begin{array}{c}\mathbf{0 . 3 6 0 6 * *} \\
(0.1771)\end{array}$ & $\begin{array}{c}\mathbf{0 . 3 2 9 7} * * \\
(0.1371)\end{array}$ & & $\begin{array}{c}\mathbf{0 . 4 7 3 8} * * \\
(0.2295)\end{array}$ & $\begin{array}{c}\mathbf{0 . 4 6 2 0} * * \\
(0.1908)\end{array}$ \\
\hline Age & & $\begin{array}{c}0.0006 \\
(0.0056)\end{array}$ & $\begin{array}{l}-0.0063 \\
(0.0044)\end{array}$ & & $\begin{array}{c}0.0055 \\
(0.0072)\end{array}$ & $\begin{array}{l}-0.0028 \\
(0.0060)\end{array}$ \\
\hline Income earners & & $\begin{array}{l}-0.3563 * \\
(0.2630)\end{array}$ & $\begin{array}{l}-0.0034 \\
(0.1723)\end{array}$ & & $\begin{array}{l}-0.3308 \\
(0.2799)\end{array}$ & $\begin{array}{c}0.0638 \\
(0.2353)\end{array}$ \\
\hline Income & & $\begin{array}{c}0.0000 \\
(0.0001)\end{array}$ & $\begin{array}{c}0.0000 \\
(0.0000)\end{array}$ & & $\begin{array}{c}0.0001 \\
(0.0001)\end{array}$ & $\begin{array}{c}0.0000 \\
(0.0001)\end{array}$ \\
\hline Family situation & & $\begin{array}{c}-\mathbf{0 . 6 7 3 1} * * * \\
(0.2560)\end{array}$ & $\begin{array}{l}-0.3028 \\
(0.1995)\end{array}$ & & $\begin{array}{c}-0.5164 * \\
(0.3138)\end{array}$ & $\begin{array}{l}-0.2386 \\
(0.2621)\end{array}$ \\
\hline $\begin{array}{l}\text { Means of technical } \\
\text { communication }(\mathrm{C} 1)\end{array}$ & 0.0514 & 0.0438 & 0.0081 & 0.0250 & 0.0301 & 0.0013 \\
\hline & $(0.0368)$ & $(0.0409)$ & $(0.0317)$ & $(0.0423)$ & $(0.0445)$ & $(0.0371)$ \\
\hline Means of mass communication & $0.2753 * * *$ & $0.2669^{* * *}$ & $0.1291^{* * *}$ & $0.2961 * * *$ & $0.3147^{* * *}$ & $0.1510 * * *$ \\
\hline & $(0.0460)$ & $(0.0529)$ & $(0.0419)$ & $(0.0606)$ & $(0.0677)$ & $(0.0580)$ \\
\hline $\begin{array}{l}\text { Attention to environmental } \\
\text { features (C3) }\end{array}$ & $0.1579 * * *$ & 0.1178 * & 0.0764 * & 0.0995 & 0.0727 & 0.0948 \\
\hline & $(0.0519)$ & $(0.0611)$ & $(0.0474)$ & $(0.0702)$ & $(0.0768)$ & $(0.0639)$ \\
\hline Angler community (C4) & $\begin{array}{c}\mathbf{0 . 1 4 1 2} * * * \\
(0.0521)\end{array}$ & $\begin{array}{c}\mathbf{0 . 1 8 2 1}^{* * *} \\
(0.0583)\end{array}$ & $\begin{array}{c}\mathbf{0 . 1 2 3 0} \\
(0.0453)\end{array}$ & $\begin{array}{c}0.0990 \\
(0.0684)\end{array}$ & $\begin{array}{l}\mathbf{0 . 1 6 5 1} * * \\
(0.0755)\end{array}$ & $\begin{array}{c}0.0787 \\
(0.0632)\end{array}$ \\
\hline Contaminant limits & & $\begin{array}{l}-0.1370 \\
(0.1735)\end{array}$ & $\begin{array}{l}-0.0880 \\
(0.1343)\end{array}$ & & $\begin{array}{l}-0.0815 \\
(0.2184)\end{array}$ & $\begin{array}{l}-0.0088 \\
(0.1818)\end{array}$ \\
\hline Store & & & $\begin{array}{c}-2.1060 * * * \\
(0.1371)\end{array}$ & & & $\begin{array}{c}-2.1850 * * * \\
(0.1987)\end{array}$ \\
\hline Other eco-products & & $\begin{array}{l}-0.2582 \\
(0.1639)\end{array}$ & $\begin{array}{c}0.0210 \\
(0.1281)\end{array}$ & & $\begin{array}{l}-0.3178 \\
(0.2130)\end{array}$ & $\begin{array}{l}-0.0268 \\
(0.1789)\end{array}$ \\
\hline Consumers' awareness & $\begin{array}{c}0.2772 \\
(0.4618)\end{array}$ & $\begin{array}{c}0.4499 \\
(0.4919)\end{array}$ & $\begin{array}{c}0.2791 \\
(0.3809)\end{array}$ & $\begin{array}{c}\mathbf{1 . 4 7 8 1 * *} \\
(0.6782)\end{array}$ & $\begin{array}{l}1.6027 * * \\
(0.7006)\end{array}$ & $\begin{array}{c}0.6757 \\
(0.5881)\end{array}$ \\
\hline R-square (Adjusted) & 0.0995 & 0.1041 & 0.4635 & 0.0777 & 0.0963 & 0.3753 \\
\hline No of cases & 454 & 364 & 364 & 350 & 307 & 307 \\
\hline
\end{tabular}

Key: C1-C4: Components 1-4; Levels of statistical significance: $<0.01\left(^{* * *}\right),<0.05\left(^{* *}\right)$, and $<0.10\left({ }^{*}\right)$; bolded digits indicate statistically significant values.

\section{Discussion}

The consumers that were aware and willing to pay a price premium for anchovy eco-labels were principally female, living alone, informed about environmental issues by means of mass communication, and had a strong intrinsic motivation to protect marine habitats. In particular, income and interest in other eco-label products seemed to influence the consumers' responsiveness to anchovies caught in certified 'blue' fishing grounds, while high-income consumers showed an interest in fish quality and its effects on human health. Other groups that related positively to the willingness to pay for anchovy eco-labels include angler communities as well as those living in coastal areas.

With respect to gender, the results obtained seem consistent with those reported elsewhere, indicating higher WTP for eco-labeled seafood for females [5,23,30-32]. However, males in the United States [30] and China [24,33] have been reported to show increased concern about the environment. In fact, men in France were reported to show more attention to responsible fishing than females [5]. Increased consumer awareness to environmental issues plays a crucial role in defining marketing strategies linked with eco-labeled seafood. In this context, global policies could support sustainable consumption and production as an instrument to maximize potential business [5]. In line with this trend, Italian hypermarket consumers in this study demonstrated a high degree of attention to environmental features as well as to eco-products, at times, independent from income, as has already been observed in several developed economies $[6,16]$. Despite this, the description given to the two 
labels—one referred to fish caught using gear with a low impact on habitats (LIH; exclusively related to the protection of commons) and the other referred to fish caught in unpolluted areas, certified 'blue' fishing grounds (BFG; related to both the protection of commons and human health) -appeared to play an important role in the consumers' preferences. In fact, the results suggest that the intrinsic motivation of consumers may be associated with aspects primarily related to BFG rather than to LIH, emphasizing that health and food safety concerns are the principal drivers in the purchasing process [23]. Moreover, consumers' attention to the condition of the product (fresh/frozen) and visual aspects, together with the exploitation level of a given species and the harvesting process (wild vs. farmed), have been deemed useful to determine consumer responsiveness to an eco-labeled seafood product $[16,23,34]$.

While eco-labelled seafood is generally perceived to be in a different category compared to fish products in general, consumers can be considered to possess a species-specific WTP [30,35-37]. Indeed, WTP would differ based on the seafood product, the initial price, the countries, and the consumers' sociodemographic characteristics [8,16,23-26,30,31,36,38]. Italian hypermarket consumers in this study showed an average WTP for anchovy eco-labels of 19\% for WTP-LIH and 24\% for WTP-BFG in Palermo and $16 \%$ for WTP-LIH and 18\% for WTP-BFG in Milan. The greater WTP in Palermo than in Milan was confirmed by the statistical significance of the variable store in Models 3 of the regression analysis (Table 6). These results, in our opinion, may well demonstrate differences in the marine knowledge of consumers in the context of their given cultural and social background. To further support this opinion, the fact that the variable angler community was statistically significant suggests an increased emphasis on marine traditions within the littoral community. Notably, these percentages should be considered as conservative values given the lack of consumer loyalty together with the increased awareness from the daily presence of anchovy eco-labels in the markets. Moreover, mass communication significantly influenced the WTP, which would suggest the growth potential for seafood eco-labels in Italian hypermarkets.

However, the anchovy is considered to be a low-priced species. As has been shown in other studies conducted in the United States, France, and Norway [25,30,39], consumers' willingness to pay is influenced by the initial price. Accordingly, the WTP for anchovy in the Italian hypermarkets of this study might be different than those for high-priced species like lobster, shrimp, and tuna [26,30,38].

In the light of these considerations, we believe that eco-labels would be more effective if they were part of a wider strategy promoting a well-defined and co-managed fisheries system, one that is able to conserve, ensure, and protect the sustainable exploitation of natural resources. Consequently, eco-labels can be concrete tools to help attain sustainable development at both a local and a global scale [40].

\section{Conclusions}

In this study, consumer responsiveness to eco-labeled anchovies has been determined with a robust modeling approach drawn from the relevant literature.

The current study has revealed that environmental features and income, among other factors, significantly influence consumer responses to eco-labeled seafood products. In addition, WTP can relate to gender, family situation, mass communication, environmental features, angler community, and store, along with information from eco-labels. Moreover, a premium on an initial price for anchovies between $16-24 \%$ appears to be feasible.

The novelty of our investigation is that the Italian consumers of this study appear to have a greater appreciation for seafood eco-labels connected to health compared to those solely related to ethical issues.

Consumers' willingness to pay reveals a new aspect of the 'ecosystem approach to fishery management' that could assist in the development of new measures to ensure the sustainable exploitation of Mediterranean marine resources. Moreover, premium prices could in fact become a lever for sustainable resource management. Through eco-labels, management authorities could 
promote the use of more selective fishing gear, reduce the number of fishing days, and support the ban on fishing within spawning and nursery grounds.

In this sense, the eco-label could offer a tool for a cultural change in the use of fishery resources, so that they can continue to be of service to future generations as they are to us today.

Author Contributions: S.V., C.G., V.P. and M.S. conceived and designed the experiments; S.V., C.G., I.P. performed the experiments; F.B., C.O.R.O., and V.P. analyzed the data; S.V., C.G., C.O.R.O., G.B., and V.P. wrote the paper. All authors have read and agreed to the published version of the manuscript.

Funding: This research was funded by Sicilian Region under POFESR Sicilia 2007/2013_-“Obiettivo Operativo 5.1.1" and project "Nuove Rotte: Blue Economy", work package "Laboratorio 1: sostenibilità e responsabilità sociale".

Acknowledgments: Our thanks go to AUCHAN S.p.A., particularly Stefano Favari, Paolo Mazzoleni, Libero Di Paola, Francesco D'India, and Giuseppe Di Lonardo. We appreciate the support of our CNR colleagues, particularly Maria Bonsignore, Marianna Del Core, Sandro Fiorelli, Nunzio Gallì, Marta Giuga, Marianna Musco, Carlo Patti, Valentina Sclifò, and Anna Traina for conducting the interviews. We thank all the participants in the annual Conference of the Italian Society of Economists (Bologna, 2018) for their kind suggestions.

Conflicts of Interest: The authors declare no conflict of interest. The funding sponsors had no role in the design of the study; in the collection, analysis, or interpretation of data; in the writing of the manuscript, and in the decision to publish the results.

\section{References}

1. Nguyen, L.Q.; Du, Q.; Friedrichs, Y.V. Effectiveness of Eco-Label? A Study of Swedish University Students' Choice on Ecological Food. Master Thesis, Umeå School of Business, Umeå, Sweden, 2010.

2. Maesano, G.; Carra, G.; Vindigni, G. Sustainable dimensions of seafood consumer purchasing behaviour: A review. Calitatea 2019, 20, 358-364.

3. Food and Agriculture Organization of the United Nations (FAO). Code of Conduct for Responsible Fisheries. 1995. Available online: http://www.fao.org/docrep/005/v9878e/v9878e00.htm (accessed on 13 June 2018).

4. Sogn-Grundvåga, G.; Larsena, T.A.; Youngb, J.A. The value of line-caught and other attributes: An exploration of price premiums for chilled fish in UK supermarkets. Mar. Policy 2013, 38, 41-44. [CrossRef]

5. Brécard, D.; Lucas, S.; Pichot, N.; Salladarré, F. Consumer Preferences for Eco. Health and Fair Trade Labels. An Application to Seafood Product in France. J. Agric. Food Ind. Organ. 2012, 10, 1-27. [CrossRef]

6. World Business Council for Sustainable Development (WBCSD). Sustainable Consumption. Facts and Trends. For a Business Perspective. 2008. Available online: http://www.wbcsd.org/Clusters/SustainableLifestyles/Resources/Sustainable-Consumption-Fact-and-Trends-From-a-Business-Perspective (accessed on 13 June 2018).

7. Clonan, A.; Holdsworth, M.; Swift, J.A.; Leibovici, D.; Wilson, P. The dilemma of healthy eating and environmental sustainability: The case of fish. Public Health Nutr. 2011, 15, 277-284. [CrossRef] [PubMed]

8. Wakamatsu, H. Heterogeneous Consumer Preference for Seafood Sustainability in Japan. 2019. Available online: https://mpra.ub.uni-muenchen.de/92390/ (accessed on 8 January 2020).

9. Jonell, M.; Crona, B.; Brown, K.; Rönnbäck, P.; Troell, M. Eco-Labeled Seafood: Determinants for (Blue) Green Consumption. Sustainability 2016, 8, 884. [CrossRef]

10. Pérez-Ramírez, M.; Almendarez-Hernández, M.; Avilés-Polanco, G.; Beltrán-Morales, L.F. Consumer Acceptance of Eco-Labeled Fish: A Mexican Case Study. Sustainability 2015, 7, 4625-4642. [CrossRef]

11. Gutierrez, A.; Thornton, T.F. Can Consumers Understand Sustainability through Seafood Eco-Labels? A U.S. and UK Case Study. Sustainability 2014, 6, 8195-8217. [CrossRef]

12. Jaffry, S.; Pickering, H.; Ghulam, Y.; Whitmarsh, D.; Wattage, P. Consumer choices for quality and sustainability labeled seafood products in the UK. Food Policy 2004, 29, 215-228. [CrossRef]

13. Johnston, R.J.; Roheim, C.A. A battle of taste and environmental convictions for ecolabeled seafood: A contingent ranking experiment. J. Agric. Resour. Econ. 2006, 31, 283-300.

14. Whitmarsh, D.; Wattage, P. Public attitude towards the environmental impact of salmon aquaculture in Scotland. Eur. Environ. 2006, 16, 108-121. [CrossRef] 
15. Salladarré, F.; Guillotreau, P.; Perraudeau, Y.; Montfort, M.C. The demand for seafood eco-labels in France. J. Agric. Food Ind. Organ. 2010, 8. [CrossRef]

16. Zander, K.; Feucht, Y. Consumers' Willingness to Pay for Sustainable Seafood Made in Europe. J. Int. Food Agribus. Mark. 2018, 30, 251-275. [CrossRef]

17. Wessells, C.R.; Johnston, R.J.; Donath, H. Assessing consumer preferences for ecolabeled seafood: The influence of species, certifier and household attributes. Am. J. Agric. Econ. 1999, 81, 1084-1089. [CrossRef]

18. Ward, T.; Phillips, B. Seafood Ecolabelling. Principles and Practice, 1st ed.; John Wiley \& Sons Blackwell Publishing: Oxford, UK, 2008.

19. Piroddi, C.; Coll, M.; Liquete, C.; Macias, D.; Greer, K.; Buszowski, J.; Steenbeek, J.; Danovaro, R.; Christensen, V. Historical changes of the Mediterranean Sea ecosystem: Modelling the role and impact of primary productivity and fisheries changes over time. Sci. Rep. 2017, 7, 44491. [CrossRef] [PubMed]

20. Carlucci, F.; Cirà, A.; Forte, E.; Siviero, L. Infrastructure and logistics divide: Regional comparisons between North Eastern \& Southern Italy. Technol. Econ. Dev. Ecol. 2017, 23, 243-269. [CrossRef]

21. Istituto Nazionale di Statistica. Il Tuo Accesso Diretto alla Statistica Italiana. Available online: http: //dati.istat.it/Index.aspx?DataSetCode=DCIS_POPRES1\# (accessed on 27 December 2019).

22. Dipartimento delle FInanze. Analisi Statistiche. Available online: https://www1.finanze.gov.it/finanze3/ analisi_stat/index.php?page=1\&tree=2014AAPFTOT0106\&\&\&export=0\&media $=$ media\&\&\&\&\&\& $($ accessed on 27 December 2019).

23. Brécard, D.; Hlaimi, B.; Lucas, S.; Perraudeau, Y.; Salladarré, F. Determinants of demand for green products: An application to eco-label demand for fish in Europe. Ecol. Econ. 2009, 69, 115-125. [CrossRef]

24. Xu, P.; Zeng, Y.; Fong, Q.; Lone, T.; Liu, Y. Chinese consumers' willingness to pay for green- and eco-labeled seafood. Food Control 2012, 28, 74-82. [CrossRef]

25. Erwann, C. Eco-labelling: A new deal for a more durable fishery management? Ocean Coast. Manag. 2009, 52, 250-257. [CrossRef]

26. Goyert, W.; Sagarin, R.; Annala, J. The promise and pitfalls of Marine Stewardship Council certification: Maine lobster as a case study. Mar. Policy 2010, 34, 1103-1109. [CrossRef]

27. Diamond, S.S. Reference Manual on Scientific Evidence, 3rd ed.; National Academies Press: Washington, DC, USA, 2011.

28. Hotelling, H. Analysis of a Complex of Statistical Variables into Principal Components. J. Educ. Psychol. 1933, 24, 417-441. [CrossRef]

29. Heckman, J.J. Sample Selection Bias as a Specification Error. Econometrica 1979, 47, 153-161. [CrossRef]

30. Johnston, R.J.; Wessells, C.R.; Donath, H.; Asche, F. Measuring Consumer Preferences for Ecolabeled Seafood: An International Comparison. J. Agric. Resour. Econ. 2001, 26, 20-39.

31. Carlsson, F.; Johansson-Stenman, O. Willingness to pay for improved air quality in Sweden. Appl. Econ. 2000, 32, 661-669. [CrossRef]

32. Dupont, D.P. Do children matter? An examination of gender differences in environmental valuation. Ecol. Econ. 2004, 49, 273-286. [CrossRef]

33. Shen, J. Understanding the Determinants of Consumers' Willingness to Pay for Eco-Labeled Products: An Empirical Analysis of the China Environmental Label. J. Serv. Sci. Manag. 2012, 5, 87-94. [CrossRef]

34. Giosuè, C.; Gancitano, V.; Sprovieri, M.; Bono, G.; Vitale, S. A responsible proposal for Italian seafood consumers'. Eur. J. Sustain. Dev. 2018, 7, 523-544. [CrossRef]

35. Andrewwstevens. Available online: http://andrewwstevens.com/wp-content/uploads/2015/06/Seafood.pdf (accessed on 13 June 2018).

36. Vitale, S.; Giosuè, C.; Biondo, F.; Bono, G.; Boscaino, G.; Sprovieri, M.; Attanasio, M. Are People Willing to Pay for Eco-Labeled Wild Seafood? An Overview. Eur. J. Sustain. Dev. 2017, 6, 20. [CrossRef]

37. Hilger, J.; Hallstein, E.; Stevens, A.W.; Villas-Boas, S.B. Measuring Willingness to Pay for Environmental Attributes in Seafood. Environ. Resour. Econ. 2019, 73, 307-332. [CrossRef]

38. Zhou, G.; Hu, W.; Huang, W. Are Consumers Willing to Pay More for Sustainable Products? A Study of Eco-Labeled Tuna Steak. Sustainability 2016, 8, 494. [CrossRef] 
39. Roheim, C.A.; Asche, F.; Santos, J.I. The elusive price premium for ecolabeled products: Evidence from seafood in the UK market. J. Agric. Econ. 2011, 62, 655-668. [CrossRef]

40. Pipitone, V.; Colloca, F. Recent trends in the productivity of the Italian trawl fishery: The importance of the socio economic context and overexploitation. Mar. Policy 2018, 87, 135-140. [CrossRef]

(C) 2020 by the authors. Licensee MDPI, Basel, Switzerland. This article is an open access article distributed under the terms and conditions of the Creative Commons Attribution (CC BY) license (http://creativecommons.org/licenses/by/4.0/). 